\title{
Loss of estrogen receptor $\beta$ decreases mitochondrial energetic potential and increases thrombogenicity of platelets in aged female mice
}

\author{
Muthuvel Jayachandran • Claudia C. Preston - Larry W. Hunter • \\ Arshad Jahangir • Whyte G. Owen • Kenneth S. Korach • Virginia M. Miller
}

Received: 28 May 2009 /Accepted: 15 October 2009/Published online: 12 November 2009

(C) The Author(s) 2009. This article is published with open access at Springerlink.com

\begin{abstract}
Platelets derived from aged (reproductively senescent) female mice with genetic deletion of estrogen receptor beta $(\beta E R)$ are more thrombogenic than those from age-matched wild-type (WT) mice. Intracellular processes contributing to this increased thrombogenicity are not known. Experiments were
\end{abstract}

M. Jayachandran $\cdot$ L. W. Hunter · V. M. Miller

Department of Surgery, Mayo Clinic College of Medicine, 200 First Street SW,

Rochester, MN 55905, USA

M. Jayachandran $(\bowtie) \cdot$ V. M. Miller

Department of Physiology and Biomedical Engineering,

Mayo Clinic College of Medicine,

200 First Street SW,

Rochester, MN 55905, USA

e-mail: jaya.m@mayo.edu

C. C. Preston · A. Jahangir

Division of Cardiovascular Diseases,

Mayo Clinic College of Medicine,

200 First Street SW,

Rochester, MN 55905, USA

W. G. Owen

Division of Hematology and Department of Biochemistry and Molecular Biology, Mayo Clinic College of Medicine, 200 First Street SW,

Rochester, MN 55905, USA

\section{K. S. Korach}

Laboratory of Reproductive and Developmental Toxicology, National Institute of Environmental Health Sciences,

Research Triangle Park, NC, USA designed to identify subcellular localization of estrogen receptors and evaluate both glycolytic and mitochondrial energetic processes which might affect platelet activation. Platelets and blood from aged (22-24 months) WT and estrogen receptor $\beta$ knockout $(\beta E R K O)$ female mice were used in this study. Body, spleen weight, and serum concentrations of follicle-stimulating hormone and $17 \beta$-estradiol were comparable between WT and $\beta E R K O$ mice. Number of spontaneous deaths was greater in the $\beta E R K O$ colony $(50 \%$ compared to $30 \%$ in WT) over the course of 24 months. In resting (nonactivated) platelets, estrogen receptors did not appear to colocalize with mitochondria by immunostaining. Lactate production and mitochondrial membrane potential of intact platelets were similar in both groups of mice. However, activities of NADH dehydrogenase, cytochrome $b c_{1}$ complex, and cytochrome $c$ oxidase of the electron transport chain were reduced in mitochondria isolated from platelets from $\beta E R K O$ compared to WT mice. There were a significantly higher number of phosphatidylserine-expressing platelet-derived microvesicles in the plasma and a greater thrombin-generating capacity in $\beta E R K O$ compared to WT mice. These results suggest that deficiencies in $\beta E R$ affect energy metabolism of platelets resulting in greater production of circulating thrombogenic microvesicles and could potentially explain increased predisposition to thromboembolism in some elderly females. 
Keywords Aging · Estrogen receptors ·

Microparticles · Mitochondria · Platelet energy metabolism $\cdot$ Procoagulant activity

\section{Introduction}

Incidence of cardiovascular disease, including thrombosis and associated events such as stroke, myocardial infarction, and pulmonary embolism, increases in women following the decline of circulating estrogen associated with menopause (Bushnell et al. 2006; Hu et al. 1999; Mari et al. 2007; Rexrode et al. 2007). The cellular basis for this increased risk is not entirely clear. Cellular responses to estrogen are initiated mostly through binding to one or both estrogen receptors $\alpha$ $(\alpha \mathrm{ER})$ and $\beta$ ( $\beta E R)$. Platelets, cytoplasmic fragments of bone marrow megakaryocytes, are required for normal hemostasis and thrombosis. Although both estrogen receptors are present in bone marrow megakaryocytes and platelets, $\beta E R$ is the predominant estrogen receptor subtype in anucleated platelets and appears to play a role in mediating aging-associated changes in platelet number and activity (Bracamonte et al. 2002; Jayachandran et al. 2003; Jayachandran and Miller 2002; Khetawat et al. 2000; Moro et al. 2005; Nagata et al. 2003). Genetic deletion of $\beta E R$ did not affect platelet characteristics in young female mice, but in aged female mice, numbers of circulating platelets, platelet aggregation, and ATP secretion from dense granules decreased, whereas number of young (reticulated) platelets and platelet procoagulant surface expression of $\mathrm{P}$-selectin and phosphatidylserine increased (Jayachandran et al. 2005).

Activation processes (aggregation and secretion) of platelets utilize energy provided by glycolysis and oxidative phosphorylation (Holmsen 1975; MerloPich et al. 2004; Salganicoff and Fukami 1972). Therefore, an energetic defect within platelets associated with aging and ER deficiency may explain increased thrombogenicity of blood in the elderly female. Both $\alpha E R$ and $\beta E R$ are associated with neuronal and cardiac mitochondria (Chen et al. 2004; Yang et al. 2004) and could regulate genes required for mitochondrial function (O'Lone et al. 2007). Activated platelets contribute to thrombotic complications by providing membrane phosphatidylserine required for thrombin generation (Bouchard and Tracy 2001; Butenas and Mann 2002). During activation, platelets shed sealed submicron-sized plasma membrane vesicles called microvesicles (or microparticles), which express phosphatidylserine on their surface and are thus thrombogenic. The present study was designed to determine how the loss of $\beta E R$ could affect energy metabolism in platelets and thus provide a link between the number and characteristics of circulating microvesicles in aged female mice. It was hypothesized that loss of $\beta E R$ would affect platelet energy metabolism to increase shedding of thrombogenic microvesicles.

\section{Methods}

Animals Three- to 4-month-old female $\alpha \mathrm{ER}^{+/+} / \beta \mathrm{ER}^{+/+}$ (wild-type (WT)) and $\alpha \mathrm{ER}^{+/+} / \beta \mathrm{ER}^{-/-}$( $\beta \mathrm{ER}$ knockout $(\beta E R K O)), C 57 B L / 6$ mice were obtained from the colony at National Institutes of Environmental Health Sciences, Research Triangle Park, NC, USA. These mice have an insertion disruption in exon3 of the mouse $\beta E R$ gene. The insert was designed to not encode any protein, and the mRNA analysis of these mice shows that all mRNA is out of frame. There is no evidence that measurable $\beta E R$ protein is produced in these mice. Animals were housed from the time of arrival until used in experiments (23-24 months of age) in stainless steel cages with five animals per cage and kept in 12-hour light/dark cycles at Mayo Clinic, Rochester, MN, USA, with free access to food (laboratory mouse chow) and water. Experiments were approved by the Institutional Animal Care and Use Committee, Mayo Clinic, Rochester, MN, USA.

Blood collection Mice were anesthetized for less than $1 \mathrm{~min}$ with isoflurane in a closed chamber. Blood was collected from the retro-orbital sinus plexus through siliconized capillary tubes coated with hirudin and tick anticoagulant peptide into $1.5-\mathrm{mL}$ polypropylene tubes containing $5 \mu \mathrm{L}$ of $100 \mu \mathrm{M}$ hirudin and $1 \mathrm{mM}$ tick anticoagulant peptide. Tubes without anticoagulant were used for serum preparation. Plasma and serum were prepared by centrifugation for $15 \mathrm{~min}$ at $3,000 \times g$ and then stored at $-20^{\circ} \mathrm{C}$ until analysis.

Hormone assays Serum follicle stimulating hormone (FSH) and plasma $17 \beta$-estradiol were measured with rodent ELISA kits from Endocrine Technologies Inc., San Francisco, CA, USA. 
Immunofluorescence Blood was diluted in an equal volume of modified Tyrode's solution $(\mathrm{NaCl}$ $137 \mathrm{mM}, \mathrm{KCl} 2.7 \mathrm{mM}, \mathrm{NaHCO}_{3} 11.9 \mathrm{mM}, \mathrm{NaH}_{2} \mathrm{PO}_{4}$ $0.41 \mathrm{mM}, \mathrm{MgCl}_{2} 1 \mathrm{mM}$, glucose $5.5 \mathrm{mM}$, HEPES $5 \mathrm{mM}, \mathrm{pH}$ 7. 4) and centrifuged at $150 \times \mathrm{g}$ for $15 \mathrm{~min}$ to obtain platelet-rich plasma (PRP). Samples $(100 \mu \mathrm{L})$ of PRP adjusted with Tyrode's solution $1 \times 10^{5}$ platelets $/ \mu 1$ were stained simultaneously with Mitotracker Red (200 nM) and plated onto 25-mm poly-L-lysine-coated glass coverslips at room temperature for $20 \mathrm{~min}$. The adherent platelets were rinsed briefly with Tyrode's solution and fixed in $2 \%$ paraformaldehyde for $10 \mathrm{~min}$. After fixation, platelets were permeabilized with $0.2 \%$ Triton X-100 for $10 \mathrm{~min}$ and then rinsed three times with Tyrode's solution. Nonspecific antibody binding sites were blocked with blocking buffer $(2 \%$ bovine serum albumin and 5\% normal goat serum) for $1 \mathrm{~h}$. Platelets were then incubated overnight at $4^{\circ} \mathrm{C}$ with primary $\alpha E R$ or $\beta E R$ antibodies at 1:50 dilution in blocking buffer. Platelets were then rinsed three times for 10 min with blocking buffer and incubated at room temperature in darkness for $1 \mathrm{~h}$ in goat antirabbit IgGconjugated Alexa Fluor-488 secondary antibody (1:200 dilution). After incubation, coverslips were rinsed three times and mounted on glass slides using ProLong Gold antifade reagent. For each experiment, controls, in which the primary antibody or Mitotracker Red were omitted, were also processed. Images were obtained using a Zeiss LSM 510 confocal laser scanning microscope equipped with a Zeiss $100 \times / 1.4$ numerical aperture oil objective and configured for dual-excitation and emission of laser signals simultaneously with DIC imaging. Optical slices, $0.8 \mu \mathrm{m}$ in thickness, were obtained of discoid platelets.

Lactate assay PRP was prepared as described above and divided into equal volumes containing the same number of platelets into one of three tubes: Tube- 1 for control (basal), tube-2 contained antimycin A $(100 \mu \mathrm{M}$ for $1 \mathrm{~h})$ to inhibit mitochondrial respiratory chain, and tube- 3 with collagen $(6 \mu \mathrm{g} / \mathrm{mL}$ for $5 \mathrm{~min})$ to induce platelet activation. After all treatments, PRP was centrifuged to pellet platelets at $2,600 \times g$ for 15 min. Platelet poor plasma was separated into another tube. Pelleted platelets were washed with tyrode buffer and then resuspended with lysis buffer and lysed by passing through 26-gauge needle for
8-10 times. Lactate concentration of platelet lysate and platelet poor plasma from control, Antimycin A, and collagen-treated samples was measured using lactate assay kit from Biovision, Moutain View, CA, USA.

Mitochondrial membrane potential in unstimulated platelets Membrane potential of mitochondria in intact platelets was determined in freshly prepared platelet-rich plasma by flow cytometry (FACSCanto ${ }^{\mathrm{TM}}$ ) using JC-1 $\left(5,5^{\prime}, 6,6^{\prime}\right.$-tetrachloro-1,1',3,3'-tetraethylbenzimidazolylcarbocyanine iodide; mitochondrial membrane potential detection kit from Cell Technology Inc., Mountain View, CA, USA). Platelets were gated by forward and size scatter. Mitochondrial membrane potential is expressed as a percentage of polarized (high-red fluorescence), partially polarized (high-red and green fluorescence), and depolarized (high green fluorescence) mitochondria.

Superoxide $\left(\mathrm{O}_{2}^{-}\right.$.) generation The rate of $\mathrm{O}_{2}^{-}$. generation from isolated mitochondria of platelets was measured as superoxide dismutase (SOD)-inhibitable ferricytochrome $c$ reduction assay using a modified method (Dzeja et al. 2003). The reaction mixture contains $0.1 \mathrm{M}$ potassium phosphate ( $\mathrm{pH}$ 7.4), $130 \mu \mathrm{M}$ acetylated cytochrome $c, 5 \mu \mathrm{M}$ rotenone, $20 \mathrm{mM}$ glutamate/malate, and $50-60 \mu \mathrm{g} / \mathrm{mL}$ mitochondrial protein. One hundred units of $\mathrm{SOD} / \mathrm{mL}$ were added to the reference cuvette. Cytochrome $c$ reduction was recorded at $37^{\circ} \mathrm{C}$ for $10 \mathrm{~min}$ by monitoring absorbance at $550-540 \mathrm{~nm}$ in the presence or absence of SOD. The production of $\mathrm{O}_{2}^{-}$. was estimated with the extinction coefficient of $19 \mathrm{mM}^{-1} \mathrm{~cm}^{-1}$. Rate of superoxide generation is expressed as nanomoles (nmoles) per minute per milligram protein.

Activity of isolated mitochondrial enzymes Activities of electron transport chain (ETC) complexes were determined as described previously (Preston et al. 2008). In brief, platelets were disrupted with two cycles of 30 seconds sonication (Branson sonifier with microtip, at level 4) and centrifuged for $15 \mathrm{~min}$ at $1,000 \times g$ to pellet unbroken cells and debris. The isolated mitochondria were disrupted by three rapid freeze-thaw cycles and treated with $1 \mathrm{mM} n$-dodecyl$\beta$-D-maltoside. Activity of complex I (NADH dehydrogenase) was measured by the rotenonesensitive reduction of ubiquinone-1 (Darley-Usmar 
Table 1 Baseline characteristics of mice

\begin{tabular}{lll}
\hline & Wild type $(n=8-10)$ & $\beta E R K O(n=8-10)$ \\
\hline Age (months) & $23-24$ & $23-24$ \\
Body weight $(\mathrm{g})$ & $33 \pm 1.8$ & $33 \pm 2.3$ \\
Spleen weight $(\mathrm{mg})$ & $189 \pm 37$ & $322 \pm 103$ \\
Serum FSH (ng/mL) & $0.7 \pm 0.1$ & $0.4 \pm 0.1$ \\
Plasma 17ß-estradiol (pg/mL) & $6 \pm 0.2$ & $8 \pm 0.9$ \\
Number of deaths in house (from 4 months to 24 months) & $6 / 20$ & $10 / 20$ \\
\hline
\end{tabular}

Data are presented as mean $\pm \mathrm{SEM}$

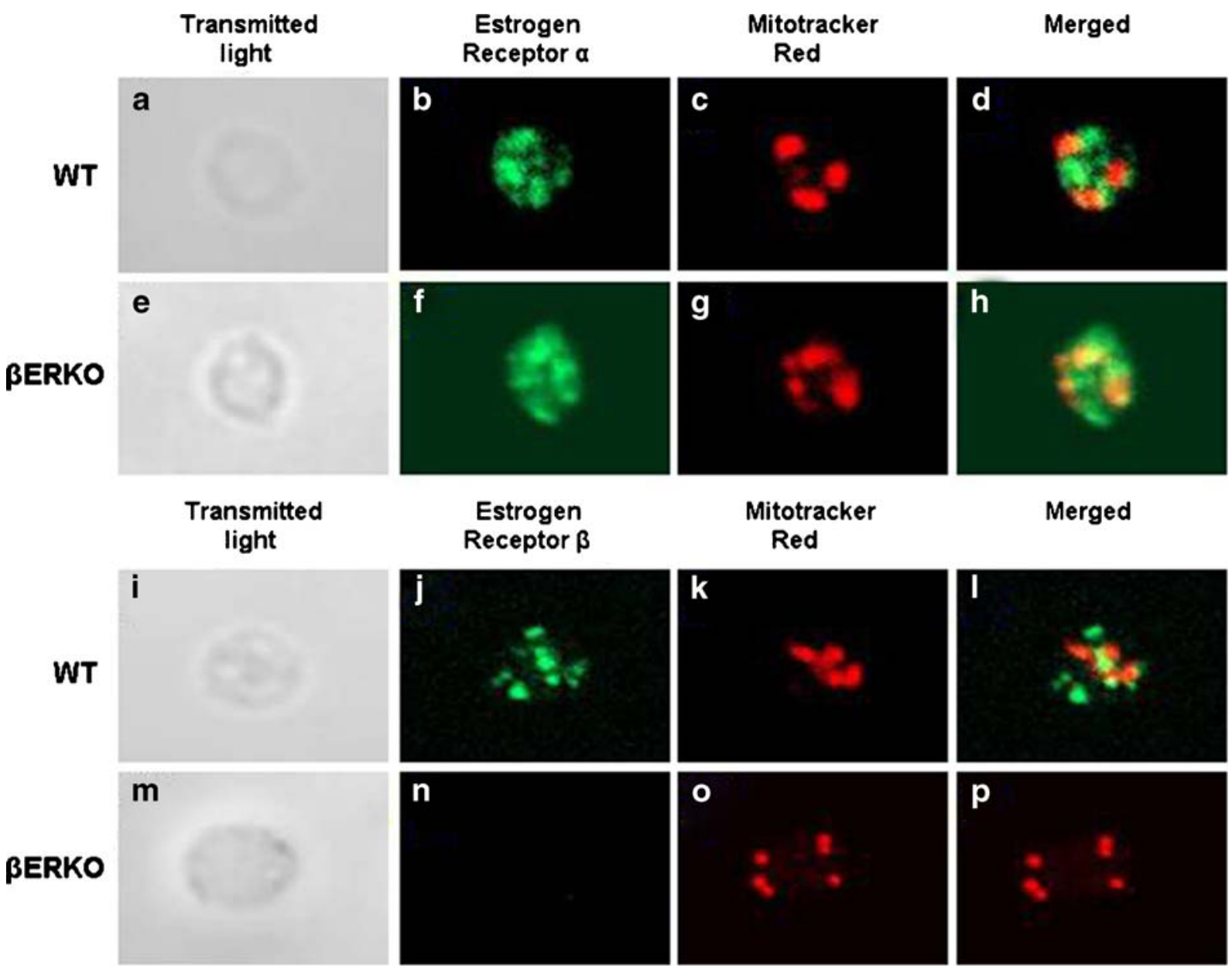

Fig. 1 Confocal laser-scanning microscopic images of immunolocalization of $\alpha E R$ and $\beta E R$ in resting mouse platelets. Shown are individual nonactivated platelets from wild type ( $a-$ $d$ for $\alpha \mathrm{ER}, i-l$ for $\beta \mathrm{ER})$ and $\beta \mathrm{ERKO}$ mice $(e-h$ for $\alpha \mathrm{ER}, m-p$ for $\beta E R)$. Left panels show differential interference-contrast images of each platelet $(a, e, i, m)$. Estrogen receptor staining is shown in green. All were costained with Mitotracker Red to identify mitochondria $(c, g, k, o)$, shown in red. Merged images showing signals from both corresponding fluorescent channels are shown in $d, h, l$, and $p$ 
Table 2 Lactate production and mitochondrial membrane potential in platelets from aged female wild type (WT) and estrogen receptor $\beta$ knockout $(\beta E R K O)$ mice (data are shown as mean \pm SEM)

${ }^{*} P<0.05$, statistically significant from control
WT $(n=8)$

$\beta \operatorname{ERKO}(n=8)$

Lactate production ( $\mathrm{nmol} / \mu \mathrm{g}$ protein)

Control

$0.06 \pm 0.01$

$0.05 \pm 0.01$

Antimycin A

$0.12 \pm 0.03$

$0.10 \pm 0.02$

Collagen

$0.13 \pm 0.02 *$

$0.12 \pm 0.02 *$

Mitochondrial membrane potential (\% number of mitochondria)

Polarized

$19 \pm 9$

$32 \pm 11$

Partially polarized

$8 \pm 2$

$6 \pm 2$

Depolarized

$56 \pm 7$
1987). Activity of complex III (cytochrome $b c_{1}$ complex) was determined by measuring reduction of decylubiquinol-cytochrome $c$ (Kwong and Sohal 2000; Trumpower and Edwards 1979). Activity of complex IV (cytochrome $c$ oxidase) activity was measured by a colorimetric assay kit (Sigma-Aldrich Inc., Saint Louis, MO). Activities of ETC complexes are expressed as nanomoles per minute per milligram protein.

Isolation of plasma microvesicles (microparticles) Platelet-free plasma was prepared by double centrifugation of anticoagulated blood at $3,000 \times \mathrm{g}$ for $15 \mathrm{~min}$.
After the platelet count $\leq 1$ was verified by Coulter counter and flow cytometry, the plasma sample $(0.2 \mathrm{~mL})$ was centrifuged at $60,000 \times \mathrm{g}$ for $30 \mathrm{~min}$. Plasma supernatants were stored at $-80^{\circ} \mathrm{C}$ for other analysis. Pelleted microvesicles were resuspended with $0.8 \mathrm{~mL}$ of twice-filtered $(0.2 \mu \mathrm{m})$ Hanks'/ HEPES buffer $\mathrm{pH} \mathrm{7.4,} \mathrm{vortexed} \mathrm{for} 2 \mathrm{~min}$, and centrifuged again at $60,000 \times \mathrm{g}$ for $30 \mathrm{~min}$ to remove plasma contaminants. After centrifugation, the supernatant was discarded, and the pellet containing the microvesicles was suspended in the above buffer and vortexed for 1-2 min prior to analysis by electron microscopy and flow cytometry.
Fig. 2 Cumulative data of activity of complex I (a; NADH dehydrogenase), complex III (b; cytochrome $b c_{1}$ complex), and complex IV (c; cytochrome $c$ oxidase) of the electron transport chain and rate of superoxide generation (d) in mitochondria isolated from platelets of aged WT and $\beta$ ERKO mice. $* P<0.05$ denotes statistical significance between aged WT and $\beta E R K O$ mice
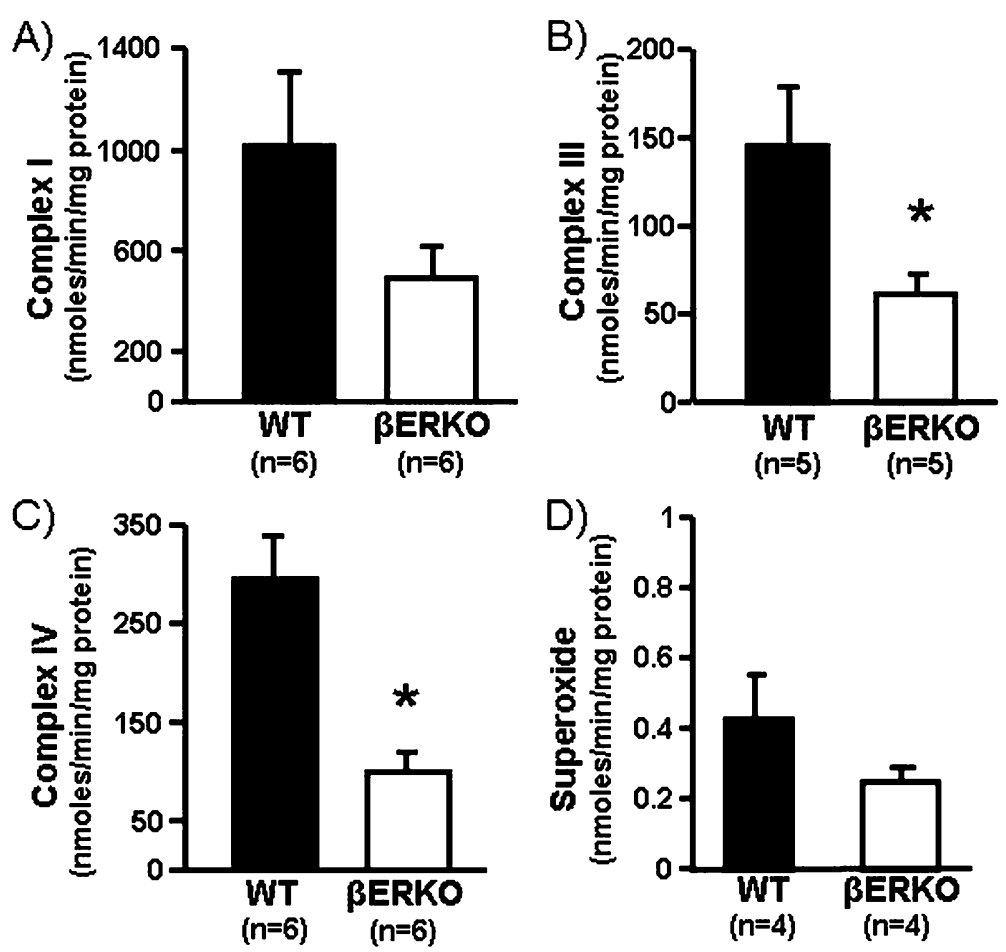
a

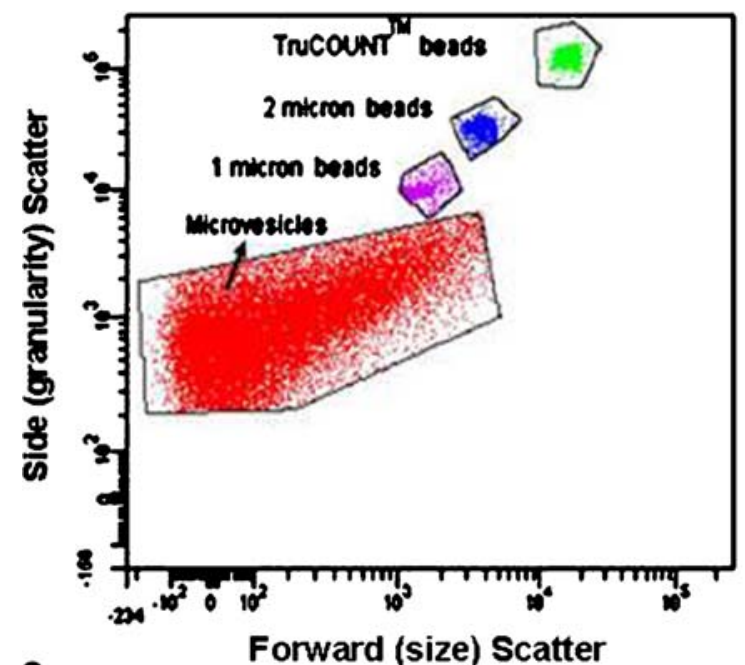

C

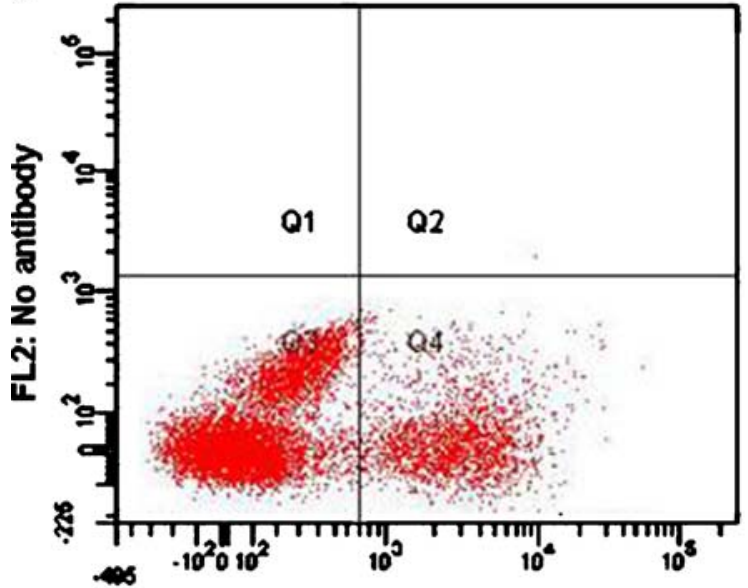

FL1: Annexin-V b

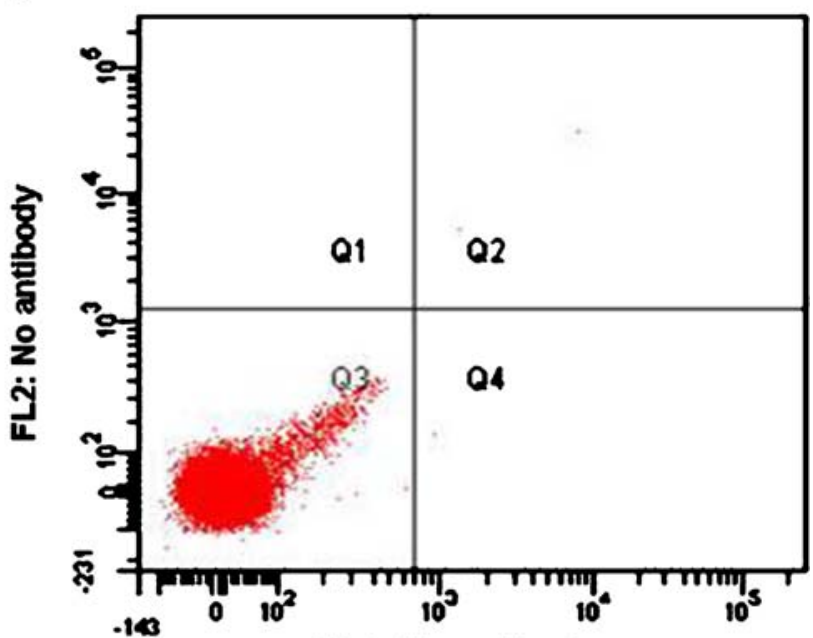

d

FL1: No antibody

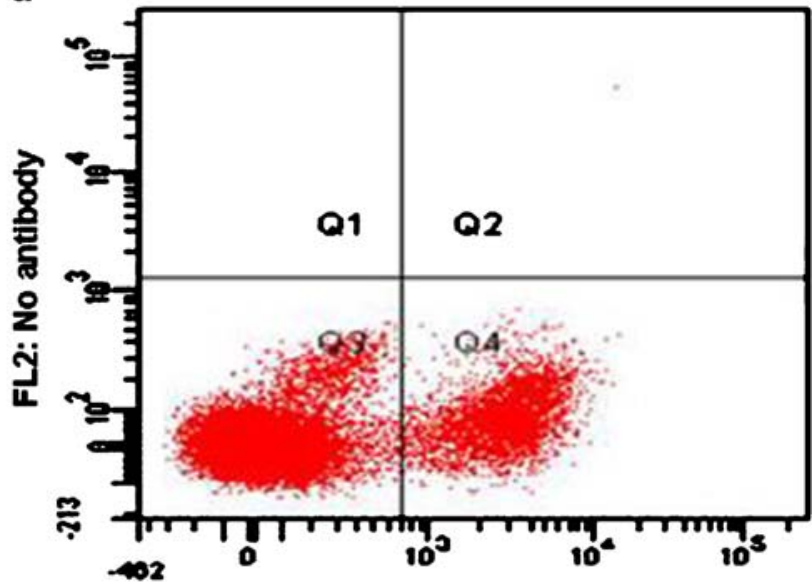

FL1: Annexin-V
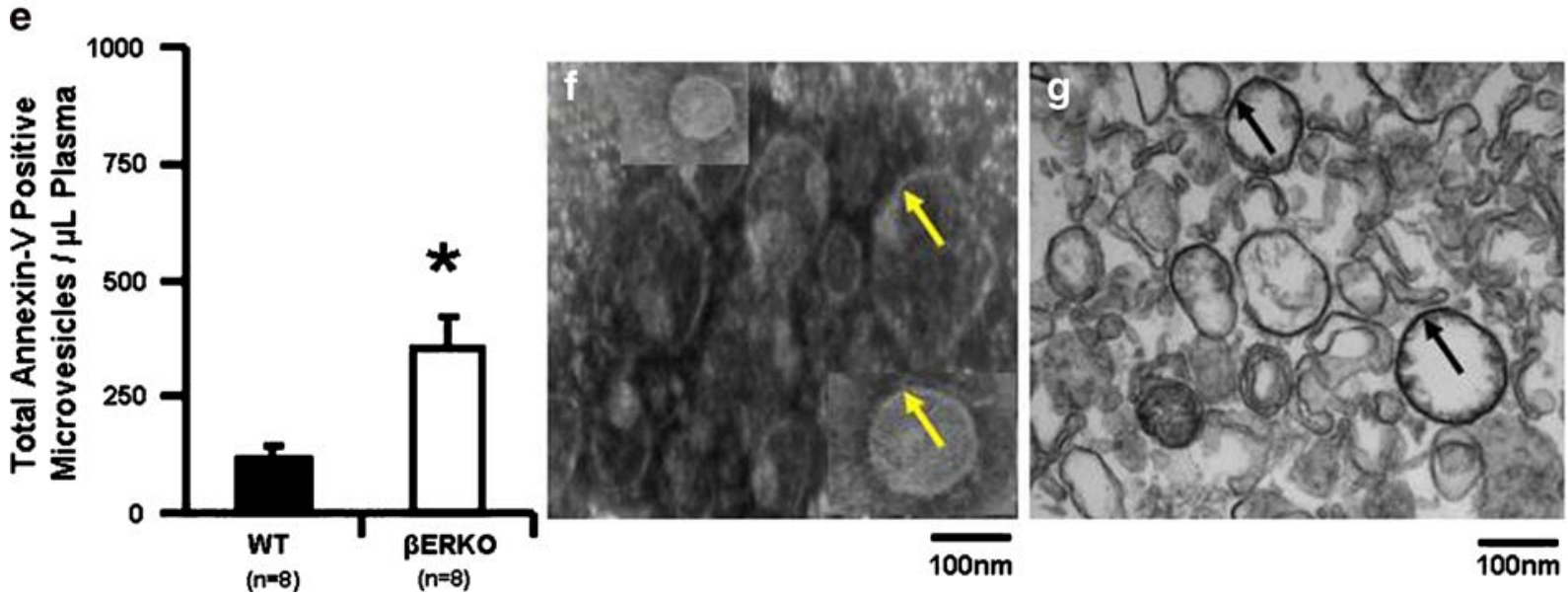
Fig. 3 Representative scatter plot of microvesicles obtained by FACSCanto $^{\mathrm{TM}}$ flow cytometry. a Gates of microvesicles with and without fluorescein-conjugated antibodies and calibration (size and TruCount ${ }^{\mathrm{TM}}$ Beads) beads. b, c, d Representative quadrants derived from the microvesicle gate shown in $\mathbf{a}$. Microvesicles only shown in b; Annexin-V-FITC labeled microvesicles from wild type (c) and $\beta E R K O$ (d) mice. Phosphatidylserine (annexin-V)-negative $(Q 3)$ and positive (Q4) microvesicles from WT and $\beta$ ERKO mice. e Cumulative data of total number of phosphatidylserine positive microvesicles from aged WT and $\beta E R K O$ mice. Representative images of scanning (f) and transmission (g) electron microscopy of isolated microvesicles from mouse blood. Arrowheads indicate membranes. ${ }^{*} P<0.05$ denotes significant difference between aged WT and $\beta$ ERKO mice

Electron microscopy Isolated microvesicles were identified by scanning and transmission electron microscopy as described previously for microvesicles from human (Jayachandran et al. 2008).

Flow cytometry Identification and characterization of isolated microvesicles from blood was described previously (Jayachandran et al. 2008). In brief, a FACSCanto $^{\mathrm{TM}}$ (BD Biosciences, San Jose, CA) was used to define microvesicles by size and positive fluorescence. Gates to define size were set with an internal standard of 1 - and $2-\mu \mathrm{m}$ beads (SigmaAldrich) and TruCOUNT ${ }^{\mathrm{TM}}$ beads (BD Biosciences, San Jose, CA). All buffers and antibodies were filtered twice through $0.2-\mu \mathrm{m}$ filter to eliminate chemical particles and reduce instrument noise. Isolated microvesicles $(50 \mu \mathrm{L})$ were incubated with $4 \mu \mathrm{L}$ of fluorescein conjugated annexin- $\mathrm{V}$ and/or combination of annexin- $\mathrm{V}$ fluorescein with phycoerythrin (PE)-conjugated platelet-specific antibodies (i.e., CD61 or CD41) and/or isotype control for $30 \mathrm{~min}$. Once stained, microvesicles were fixed with $400 \mu \mathrm{L}$ of $1 \%$ paraformaldehyde for $15 \mathrm{~min}$, and $50 \mu \mathrm{L}$ of TruCOUNT ${ }^{\mathrm{TM}}$ beads were added to enable intensities of isotype control and absolute vesicle/ particle counts. The threshold for positively stained microvesicles was set using isotype control antibodies conjugated with PE. In addition, microvesicles prepared and stained in phosphate-buffered saline or HEPES buffered saline $\mathrm{pH} 7.4$ without calcium were used as negative controls for annexin- $\mathrm{V}$ positivity. Flow cytometric acquisition of microvesicles was stopped automatically after acquiring 30,000 events or after $3 \mathrm{~min}$. Outer leaflet phosphatidylserine and platelet-derived microvesicles were identified with
annexin-V-Fluorescein isothiocyanate (FITC) and hamster antimouse CD61 (integren $\beta_{3}$ )-phycoerythrin $(\mathrm{CD} 61-\mathrm{PE})$ and/or rat antimouse CD41 ( $\alpha \mathrm{IIb})-\mathrm{PE}$, respectively (Jayachandran et al. 2008). The absolute number of microvesicles was calculated from the number of events in the region containing microvesicles divided by the number of events in the calibration bead region times the number of calibration beads per test volume (Jayachandran et al. 2008). Phosphatidylserine and platelet-derived microvesicles are expressed as number per microliter plasma.

Procoagulant activity Microvesicles (20,000 in Hanks'/HEPES) were incubated in Tyrode's solution containing $5 \mathrm{nM}$ human Factor Xa and $10 \mathrm{nM}$ human Factor $\mathrm{Va}$ at $37^{\circ} \mathrm{C}$ for $3 \mathrm{~min}$. Then, $2-\mu \mathrm{M}$ human prothrombin and $50-\mu \mathrm{M}$ fluorogenic substrate (D-VPR-ANSNH- $\mathrm{C}_{4} \mathrm{H}_{9} \cdot 2 \mathrm{HCl}$ ) were added, and the change in fluorescence was measured immediately with $\lambda_{\mathrm{ex}}=355$ and $\lambda_{\mathrm{em}}=450 \mathrm{~nm}$ for $10 \mathrm{~min}$. Thrombin generation is expressed as relative fluorescence vs time.

Materials Antibodies were purchased as follows: FITC- and PE-conjugated purified recombinant annexin-V, PE-conjugated hamster antimouse CD61 (CD61-PE), and rat antimouse CD41 (CD41-PE) monoclonal antibodies were from BD PharMingen International, San Diego, CA, USA. Rabbit antihuman estrogen receptor $\alpha$ (H184) and $\beta$ (H150; recognizes 150 amino acids of the $\mathrm{N}$ terminus of the $\beta$-receptor) polyclonal antibodies were from Santacruz Biotechnology, Santa Cruz, CA, USA. Rabbit antihuman estrogen receptor $\beta$ (ERb11-A; recognizes 16 amino acids on the C terminus) was from Alpha Diagnostic International, San Antonio, TX, USA. Mitotracker Red CMXRos, ProLong Gold antifade reagent, Alexa Fluor-conjugated goat antirabbit IgG, and normal goat serum were from Molecular Probes, Eugene, OR. Collagen (equine tendon) was from Helena Laboratories, Beaumont, TX, USA. HEPES, Hanks' balanced salts, mouse thrombin, bovine serum albumin, and poly-L-lysine were purchased from Sigma Chemical Co., St. Louis, $\mathrm{MO}$, USA. Lactate assay kit was from Biovision, Mountain View, CA, USA. Paraformaldehyde (16\% solution, EM grade) purchased from Electron Microscopy Sciences, Hatfield, PA, USA. All other reagents and solvents used in this study were of analytical/ reagents grade. 
a

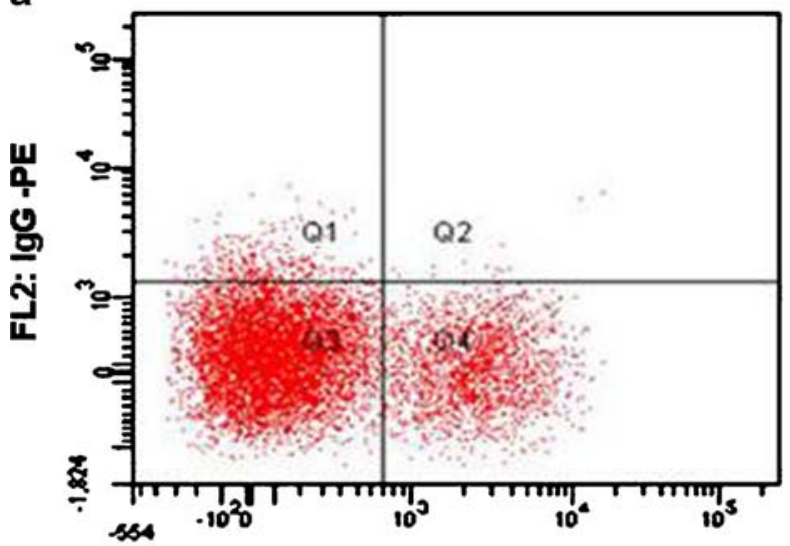

FL1: Annexin-V

C

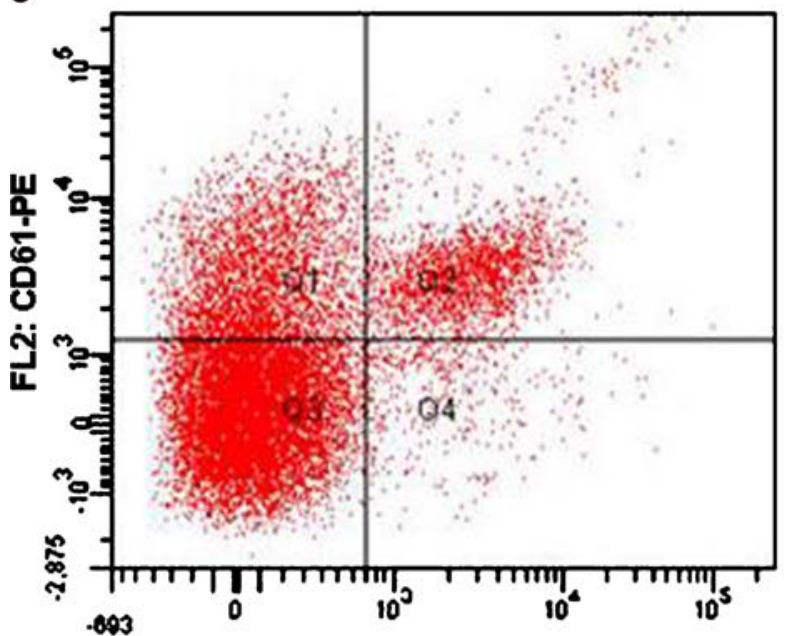

FL1: Annexin-V

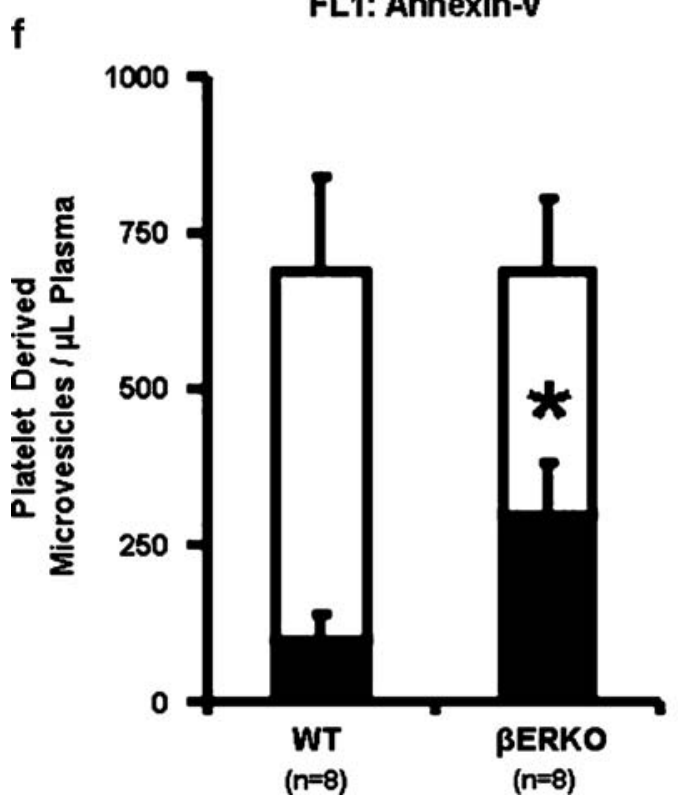

b

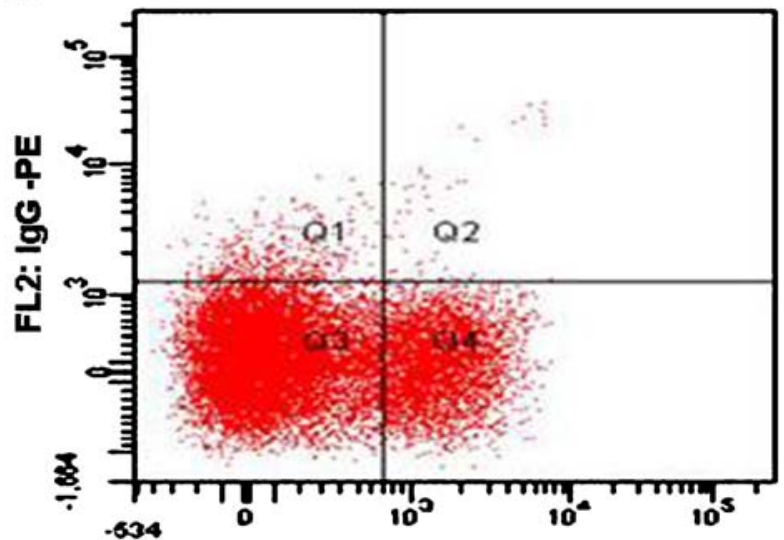

d

FL1: Annexin-V

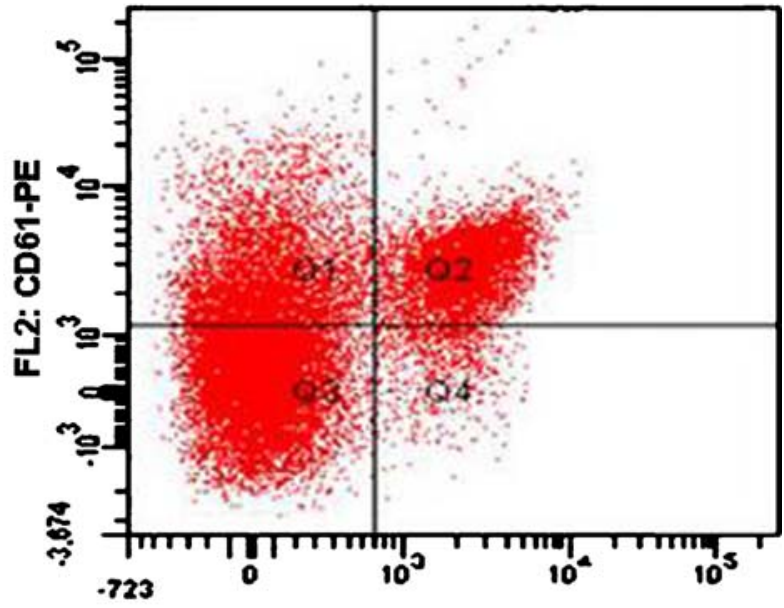

FL1: Annexin-V

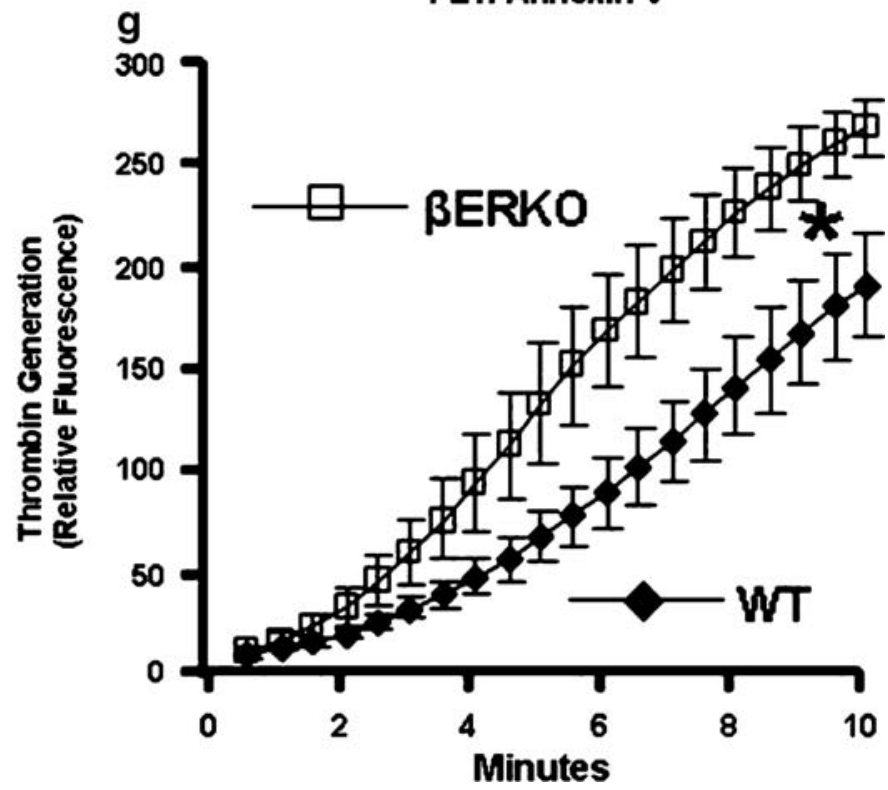


Fig. 4 Representative quadrants of PE-conjugated isotype IgG (a WT and b $\beta$ ERKO) and PE-conjugated CD61 antibody (c WT and $\mathbf{d} \beta E R K O)$ in combination with fluoresceinconjugated annexin- $\mathrm{V}$ derived from scatter plots of microvesicles obtained by FACSCanto ${ }^{\mathrm{TM}}$ flow cytometry (see Fig. 3a). e Cumulative data of number of platelet-derived (Q1 + Q2, unfilled) microvesicles from aged WT and $\beta E R K O$ mice, and proportion of those which are stained-positive for phosphatidylserine (Q2, filled). f Thrombin generation by microvesicles $(20,000)$ derived from wild type ( $n=8$; filled diamond $)$ and $\beta$ ERKO ( $n=8$; open square) mice. ${ }^{*} P<0.05$ denotes significant difference between aged WT and $\beta E R K O$ mice

Statistical analysis Statistical significance was evaluated by two-tailed unpaired Student's $t$ test. Statistical significance was accepted at $P<0.05$. All values are presented as mean \pm SEM. All experiments were carried out independently; $n$ equals the number of individual mice from wild-type and $\beta$ ERKO colonies.

\section{Results}

Body and spleen weights were similar between wild type and $\beta E R K O$ mice; concentrations of serum FSH and plasma estradiol were also comparable between groups (Table 1). Of the 20 mice in each group, six $(30 \%)$ WT and ten $(50 \%) \beta E R K O$ died during the course of 24 months. Autopsies were not performed on these animals; cause of death was not determined. Among the ten $\beta$ ERKO mice surviving until sacrifice, two had ovarian tumors, whereas none of surviving WT animals had similar tumors $(n=14)$. Mice with tumors were excluded from this study.

Both estrogen receptors $\alpha$ and $\beta$ were identified in platelets of WT mice by immunofluorescence. Most platelets had three to seven mitochondria. In both mouse types, $\alpha$ ER staining was easily identified as diffuse labeling throughout each platelet with additional small distinct regions of higher concentration. The antibody which recognized the $\mathrm{C}$ terminus of the $\beta E R$ gave inconsistent staining, and in some cases, scant positive staining was observed in platelets from $\beta E R K O$ mice. On the contrary, the antibody which recognized the $N$ terminus of $\beta E R$ was punctuated in platelets from WT mice and absent in platelets from BERKO mice (Fig. 1). There was little to no colocalization of ERs with mitochondria (Fig. 1).

Lactate concentrations in plasma containing fixed number of platelets did not change significantly following either inhibition of mitochondrial respiratory chain with antimycin A or activation with collagen and did not differ in plasma from WT and $\beta E R K O$ mice (data not shown). Lactate concentrations in platelet lysates increased by $50 \%$ following inhibition of mitochondrial respiration with antimycin A and by $60-70 \%$ following collagen activation in both groups of mice (Table 2). The mitochondrial membrane potentials of intact platelets from $\beta E R K O$ and WT mice were not significantly different (Table 2). Activities of electron transport chain complexes I, III, and IV and the generation of superoxide were about $45-50 \%$ lower in mitochondria from $\beta E R K O$ compared to WT mice reaching statistical significance at $P<0.05$ for complex III and IV (Fig. 2). Activities of complex II (succinate dehydrogenase) and complex V (ATP-synthase) were not detectable (below the detection limit of our assay) in isolated mitochondria of platelets from either group of mice (data not shown).

Isolated microvesicles from both $\beta E R K O$ and WT mice were heterogeneous in size (Fig. 3). The total number of annexin- $\mathrm{V}$ positive microvesicles was significantly greater in $\beta E R K O$ mice (Fig. 3). Although, the overall concentration of microvesicles derived from platelets (CD61 or CD41 positive) was similar between WT and $\beta E R K O$, the proportion of those which were positive for annexin- $\mathrm{V}$ was significantly higher in $\beta E R K O$ mice (Fig. 4). Thrombin generating capacity of microvesicles was associated with annexin-V (surface phosphatidylserine) positivity and was significantly greater in $\beta E R K O$ mice compared to WT (Fig. 4).

\section{Discussion}

Platelets generate energy during activation and granular secretion by both glycolysis and oxidative phosphorylation. Results of the present study demonstrate that loss of $\beta E R$ did not alter anaerobic energy metabolism of intact platelets as determined by lactate production at baseline and following inhibition of mitochondrial respiration or platelet activation by collagen. However, the capacity for oxidative metabolism was diminished in platelets from aged female mice lacking $\beta E R$ as evidenced by reduced activities of enzymes of the electron transport chain enzymes and generation of superoxide in isolated mitochondria when compared to age-matched WT mice. These observations 
are consistent with decreases in energy requiring functions (aggregation and granular secretion) of platelets from aged $\beta E R K O$ mice (Jayachandran et al. 2005). The overall decrease in oxidative capacity of these platelets in the absence of $\beta E R$ may result in decreased viability of platelets and increased release of activated membrane microvesicles.

In other cells, estrogen can modulate mitochondrial functions including ATP synthesis and mitochondrial membrane potential, but it is unclear whether these actions are estrogen receptor-dependent mechanisms (Irwin et al. 2007; Nilsen and Brinton 2004; Nilsen et al. 2007). The plasma levels of $17 \beta$-estradiol in the present study were less than those reported by others and likely reflect their reproductive senescence at 24 months of age (Couse et al. 2003, 2004). The presence of ovarian tumors in the $\beta E R K O$ mice is similar to what has been described in women with ovarian cancers associated with low expression of $\beta E R$ (Bardin et al. 2004). It was not possible to determine if these cancers were responsible for the increased mortality of the aged $\beta E R K O$ mice.

Although both $\alpha E R$ and $\beta E R$ are present in platelets, $\beta E R$ is the predominant ER in platelets of humans, pigs, and mice (Jayachandran and Miller 2002, 2003; Jorgensen et al. 1972; Khetawat et al. 2000). However, a consistent subcellular localization of $\beta$ ER has not been established, as the receptor has been identified in mitochondria of primary cultures of rat neurons and cardiomyocytes, a murine hippocampal cell line, MCF-10F and trMCF cells, and human heart (Yang et al. 2004) but not in mitochondria of mouse liver and human $\mathrm{T}$ leukemia cells (Rezaul et al. 2005; Schwend and Gustafsson 2006). A high-quality antibody with high specificity for $\beta E R$ is lacking and may account for these inconsistent findings. The immunofluorescence analysis in this study showed that $\beta E R$ did not appear to colocalize with mitochondria of nonactivated (resting) platelets from aged female mice. The antibody used to detect $\beta E R$ was produced against the N-terminal amino acid 1 to 150 of the protein. A potential limitation of this study was that other antibodies developed against other epitopes were not evaluated. In addition, direct analysis of $\beta E R$ in isolated mitochondria was not feasible because of limited amounts of mitochondria in platelets. In the future, alternative techniques need to be applied to address this question.
Measures of platelet mitochondrial functions have been proposed to be used as peripheral biomarkers for diseases associated with aging (Biagini et al. 1998; Lenaz et al. 1998; Merlo Pich et al. 1996). Mitochondrial oxidative phosphorylation and ATP synthesis decline in platelets with aging, which is accompanied by increases in mitochondrial DNA damage and free radical production (Cortopassi and Wong 1999; Lee and Wei 2000; Xu et al. 2007). A simple biochemical phenomenon, Pasteur effect (a decreased mitochondrial function induce glycolysis in order to maintain a constant ATP synthesis in a cell) can be used to determine both glycolytic and mitochondrial ATP generation (D'Aurelio et al. 2001). Lactate production after inhibition of mitochondrial respiration differentiates relative glycolytic and mitochondrial ATP production. Lactate production and the ratio of oxidative ATP over glycolytic ATP are decreased in platelets from aged individuals suggesting that there is a decrease in ATP utilization with aging (Lenaz et al. 2000). In the present study, lactate production after inhibition of mitochondrial respiratory chain with Antimycin A or platelet activation with collagen was similar in platelets from aged WT and $\beta E R K O$ mice. Likewise, in intact unstimulated platelets, mitochondrial membrane potential, a sensitive measure of mitochondrial function used as indicator of cell survival and platelet quality (Bertino et al. 2003; Leaver et al. 2006; Verhoeven et al. 2005; Wadhawan et al. 2004), was not different between WT and $\beta$ ERKO mice. However, it is not clear how mitochondrial ATP production might vary between groups when the platelets would be stimulated with an agonist, for example, thrombin, thromboxane, or ATP. Additional studies are needed to clarify these issues.

Mitochondrial electron transport, ATP synthesis, and generation of reactive oxygen species are linked. Enzyme complexes of the electron transport chain are composed of subunits encoded by nuclear as well as mitochondrial DNA. With aging, there are decreases in the gene transcripts and functional activities of oxidative phosphorylation complexes in the rat heart and mitochondrial proteins in the mouse heart (Chakravarti et al. 2008; Preston et al. 2008). In mitochondria isolated from platelets of aged $\beta E R K O$ mice, activities of oxidative phosphorylation complexes and superoxide production were lower compared to WT mice. As estrogen receptors regulate genes of the electron transport chain and reactive oxygen species generating 
pathways (O'Lone et al. 2007), effect of $\beta E R$ on regulation of these enzymes at the transcription and translational level warrants further investigation.

In a previous study of aged female mice, loss of $\beta E R$ was associated with increased numbers of circulating activated platelets (Jayachandran et al. 2005). Consistent with this finding is the observation from the present study of increased number of platelet-derived phosphatidylserine (annexin-V)-positive microvesicles (marker of in vivo platelet activation) and their thrombogenic capacity (procoagulant activity) in $\beta E R K O$ mice. Platelet- derived microvesicles are associated with thrombosis and thrombosisassociated events (Barry and FitzGerald 1999; Barry et al. 1998; Berckmans et al. 2001; Forlow et al. 2000; Heijnen et al. 1999; Horstman and Ahn 1999; Jy et al. 1995, 1999; Merten et al. 1999; Morel et al. 2006; VanWijk et al. 2003; Zwaal and Schroit 1997). Thus, this activated state of platelets may account for lower total number of circulating platelets and increased number of new (reticulated) platelets, reflecting increased production of platelets in aged $\beta E R K O$ compared to WT mice (Jayachandran et al. 2005). Increased procoagulant state in the $\beta E R K O$ mice may be responsible for the greater number of spontaneous deaths in this group over the 2 years of aging, which was also observed in mice with experimentally induced myocardial infarction (Pelzer et al. 2005).

In conclusion, the thrombin-generating capacity and number of platelet-derived phosphatidylserinepositive microvesicles increase with age in female $\beta E R K O$ mice. Increased shedding platelet microvesicles may result from decreases in activity of enzymes of the mitochondrial electron transport chain. In women, polymorphisms in $\beta E R$ are associated with thrombotic events including myocardial infarction, venous ulceration, and deep vein thrombosis (Alessio et al. 2007; Ashworth et al. 2008; Rexrode and Manson 2007). Results of present study provide one possible mechanism of how loss of $\beta$ ER may increase thrombotic events in aged women by increasing activation of platelets and shedding of thrombogenic microvesicles in the circulation.

Acknowledgment This work is supported by the National Institutes of Health (NHLBI HL78638 and NHLBI HL089542), the National Institute of Aging (AG 21201), the American Heart Association (AHA 08-30503Z), the Mayo Foundation, and Division of Intramural Research of the NIEHS.
Open Access This article is distributed under the terms of the Creative Commons Attribution Noncommercial License which permits any noncommercial use, distribution, and reproduction in any medium, provided the original author(s) and source are credited.

\section{References}

Alessio AM, Hoehr NF, Siqueira LH, Ozelo MC, de Padua Mansur A, Annichino-Bizzacchi JM (2007) Association between estrogen receptor alpha and beta gene polymorphisms and deep vein thrombosis. Thromb Res 120:639-645

Ashworth JJ, Smyth JV, Pendleton N, Horan M, Payton A, Worthington J, Ollier WE, Ashcroft GS (2008) Polymorphisms spanning the $0 \mathrm{~N}$ exon and promoter of the estrogen receptor-beta (ERbeta) gene ESR2 are associated with venous ulceration. Clin Genet 73:55-61

Bardin A, Hoffmann P, Boulle N, Katsaros D, Vignon F, Pujol P, Lazennec G (2004) Involvement of estrogen receptor beta in ovarian carcinogenesis. Cancer Res 64:5861-5869

Barry OP, FitzGerald GA (1999) Mechanisms of cellular activation by platelet microparticles. Thromb Haemost 82:794-800

Barry OP, Pratico D, Savani RC, FitzGerald GA (1998) Modulation of monocyte-endothelial cell interactions by platelet microparticles. J Clin Invest 102:136-144

Berckmans RJ, Neiuwland R, Boing AN, Romijn FP, Hack CE, Sturk A (2001) Cell-derived microparticles circulate in healthy humans and support low grade thrombin generation. Thromb Haemost 85:639-646

Bertino AM, Qi XQ, Li J, Xia Y, Kuter DJ (2003) Apoptotic markers are increased in platelets stored at 37 degrees $\mathrm{C}$. Transfusion 43:857-866

Biagini G, Pallotti F, Carraro S, Sgarbi G, Pich MM, Lenaz G, Anzivino F, Gualandi G, Xin D (1998) Mitochondrial DNA in platelets from aged subjects. Mech Ageing Dev 101:269-275

Bouchard BA, Tracy PB (2001) Platelets, leukocytes, and coagulation. Curr Opin Hematol 8:263-269

Bracamonte MP, Rud KS, Owen WG, Miller VM (2002) Ovariectomy increases mitogens and platelet-induced proliferation of arterial smooth muscle. Am J Physiol Heart Circ Physiol 283:H853-H860

Bushnell CD, Hurn P, Colton C, Miller VM, del Zoppo G, Elkind MSV, Stern BJ, Herrington D, Ford-Lynch G, Gorelick P, James A, Brown CM, Choi ES, Bray P, Newby LK, Goldstein LB, Simpkins J (2006) Advancing the study of stroke in women: summary and recommendations for future research from an NINDS-sponsored multidisciplinary working group. Stroke 37:2387-2399. doi:10.1161/01. STR.0000236053.37695.15

Butenas S, Mann KG (2002) Blood coagulation. Biochemistry $67: 3-12$

Chakravarti B, Oseguera M, Dalal N, Fathy P, Mallik B, Raval A, Chakravarti DN (2008) Proteomic profiling of aging in the mouse heart: altered expression of mitochondrial proteins. Arch Biochem Biophys 474:22-31 
Chen JQ, Delannoy M, Cooke C, Yager JD (2004) Mitochondrial localization of ERalpha and ERbeta in human MCF7 cells. Am J Physiol Endocrinol Metab 286:E1011-E1022

Cortopassi GA, Wong A (1999) Mitochondria in organismal aging and degeneration. Biochim Biophys Acta 1410:183-193

Couse JF, Yates MM, Walker VR, Korach KS (2003) Characterization of the hypothalamic-pituitary-gonadal axis in estrogen receptor (ER) Null mice reveals hypergonadism and endocrine sex reversal in females lacking ERalpha but not ERbeta. Mol Endocrinol 17:1039-1053

Couse JF, Yates MM, Sanford R, Nyska A, Nilson JH, Korach KS (2004) Formation of cystic ovarian follicles associated with elevated luteinizing hormone requires estrogen receptor-beta. Endocrinology 145:4693-4702

Darley-Usmar VM (1987) The molecular aetiology of human mitochondrial myopathies. Biochem Soc Trans 15:102-103

D’Aurelio M, Merlo Pich M, Catani L, Sgarbi GL, Bovina C, Formiggini G, Parenti Castelli G, Baum H, Tura S, Lenaz G (2001) Decreased Pasteur effect in platelets of aged individuals. Mech Ageing Dev 122:823-833

Dzeja PP, Bast P, Ozcan C, Valverde A, Holmuhamedov EL, Van Wylen DG, Terzic A (2003) Targeting nucleotiderequiring enzymes: implications for diazoxide-induced cardioprotection. Am J Physiol Heart Circ Physiol 284: H1048-H1056

Forlow SB, White EJ, Barlow SC, Feldman SH, Lu H, Bagby GJ, Beaudet AL, Bullard DC, Ley K (2000) Severe inflammatory defect and reduced viability in CD18 and E-selectin double-mutant mice. J Clin Invest 106:14571466

Heijnen HF, Schiel AE, Fijnheer R, Geuze HJ, Sixma JJ (1999) Activated platelets release two types of membrane vesicles: microvesicles by surface shedding and exosomes derived from exocytosis of multivesicular bodies and alpha-granules. Blood 94:3791-3799

Holmsen H (1975) Biochemistry of the platelet release reaction. Ciba Found Symp 35:175-205

Horstman LL, Ahn YS (1999) Platelet microparticles: a wideangle perspective. Crit Rev Oncol Hematol 30:111-142

$\mathrm{Hu}$ FB, Grodstein F, Hennekens CH, Colditz GA, Johnson M, Manson JE, Rosner B, Stampfer MJ (1999) Age at natural menopause and risk of cardiovascular disease. Arch Intern Med 159:1061-1066

Irwin RW, Yao J, Hamilton RT, Cadenas E, Brinton RD, Nilsen J (2007) Progesterone and estrogen regulate oxidative metabolism in brain mitochondria. Endocr J 149:3167-3175

Jayachandran M, Miller VM (2002) Ovariectomy upregulates expression of estrogen receptors, NOS, and HSPs in porcine platelets. Am J Physiol:Heart Circ Physiol 283: H220-H226

Jayachandran M, Miller VM (2003) Human platelets contain estrogen receptor $\alpha$, caveolin-1 and estrogen receptor associated proteins. Platelets 14:75-81

Jayachandran M, Karnicki K, Miller RS, Owen WG, Korach KS, Miller VM (2005) Platelet characteristics change with aging: role of estrogen receptor $\beta$. J Gerontol: Biol Sci 60:815-819

Jayachandran M, Litwiller RD, Owen WG, Heit JA, Behrenbeck TR, Mulvagh SL, Araoz PA, Budoff MJ, Harman SM, Miller VM (2008) Characterization of blood borne microparticles as markers of premature coronary calcification in recently menopausal women. Am J Physiol Heart Circ Physiol 295:931-938

Jorgensen L, Packham MA, Rowsell HC, Mustard JF (1972) Deposition of formed elements of blood on the intima and signs of initial injury in the aorta of rabbit, pig, and man. Lab Invest 27:341-350

Jy W, Mao WW, Horstman L, Tao J, Ahn YS (1995) Platelet microparticles bind, activate and aggregate neutrophils in vitro. Blood Cells Mol Dis 21:217-231 discussion 231a

Jy W, Mao WW, Horstman LL, Valant PA, Ahn YS (1999) A flow cytometric assay of platelet activation marker P-selectin (CD62P) distinguishes heparin-induced thrombocytopenia (HIT) from HIT with thrombosis (HITT). Thromb Haemost 82:1255-1259

Khetawat G, Faraday N, Nealen ML, Vijayan KV, Bolton E, Noga SJ, Bray PF (2000) Human megakaryocytes and platelets contain the estrogen receptor $\beta$ and androgen receptor (AR): testosterone regulates $\mathrm{AR}$ expression. Blood 95:2289-2296

Kwong LK, Sohal RS (2000) Age-related changes in activities of mitochondrial electron transport complexes in various tissues of the mouse. Arch Biochem Biophys 373:16-22

Leaver HA, Schou AC, Rizzo MT, Prowse CV (2006) Calciumsensitive mitochondrial membrane potential in human platelets and intrinsic signals of cell death. Platelets 17:368-377

Lee HC, Wei YH (2000) Mitochondrial role in life and death of the cell. J Biomed Sci 7:2-15

Lenaz G, Cavazzoni M, Genova ML, D'Aurelio M, Merlo Pich M, Pallotti F, Formiggini G, Marchetti M, Parenti Castelli G, Bovina C (1998) Oxidative stress, antioxidant defences and aging. BioFactors (Oxford, England) 8:195-204

Lenaz G, D'Aurelio M, Pich MM, Genova ML, Ventura B, Bovina C, Formiggini G, Parenti Castelli G (2000) Mitochondrial bioenergetics in aging. Biochim Biophys Acta 1459:397-404

Mari D, Coppola R, Provenzano R (2007) Hemostasis factors and aging. Exp Gerontol 43(2):66-73

Merlo Pich M, Bovina C, Formiggini G, Cometti GG, Ghelli A, Parenti Castelli G, Genova ML, Marchetti M, Semeraro S, Lenaz G (1996) Inhibitor sensitivity of respiratory complex I in human platelets: a possible biomarker of ageing. FEBS Lett 380:176-178

Merlo-Pich M, Deleonardi G, Biondi A, Lenaz G (2004) Methods to detect mitochondrial function. Exp Gerontol 39:277-281

Merten M, Pakala R, Thiagarajan P, Benedict CR (1999) Platelet microparticles promote platelet interaction with subendothelial matrix in a glycoprotein IIb/IIIa-dependent mechanism. Circulation 99:2577-2582

Morel O, Toti F, Hugel B, Bakouboula B, Camoin-Jau L, Dignat-George F, Freyssinet JM (2006) Procoagulant microparticles: disrupting the vascular homeostasis equation? Arterioscler Thromb Vasc Biol 26:2594-2604

Moro L, Reineri S, Piranda D, Pietrapiana D, Paolo L, Bertoni A, Graziani A, Defilippi P, Canobbio I, Torti M, Sinigaglia F (2005) Non-genomic effects of $17 \beta$-estradiol in human platelets: Potentiation of thrombin-induced aggregation through estrogen receptor $\beta$ and SRC kinase. Blood 105:115-121 
Nagata Y, Yoshikawa J, Hashimoto A, Yamamoto M, Payne AH, Todokoro K (2003) Proplatelet formation of megakaryocytes is triggered by autocrine-synthesized estradiol. Genes Dev 17:2864-2869

Nilsen J, Brinton RD (2004) Mitochondria as therapeutic targets of estrogen action in the central nervous system. Curr Drug Targets CNS Neurol Disord 3:297-313

Nilsen J, IR W, Gallaher TK, Brinton RD (2007) Estradiol in vivo regulation of brain mitochondrial proteome. J Neurosci 27:14069-14077

O'Lone R, Knorr K, Jaffe IZ, Schaffer ME, Martini PG, Karas RH, Bienkowska J, Mendelsohn ME, Hansen U (2007) Estrogen receptors alpha and beta mediate distinct pathways of vascular gene expression, including genes involved in mitochondrial electron transport and generation of reactive oxygen species. Mol Endocrinol 21:1281-1296

Pelzer T, Loza PA, Hu K, Bayer B, Dienesch C, Calvillo L, Couse JF, Korach KS, Neyses L, Ertl G (2005) Increased mortality and aggravation of heart failure in estrogen receptor-beta knockout mice after myocardial infarction. Circulation 111:1492-1498

Preston CC, Oberlin AS, Holmuhamedov EL, Gupta A, Sagar S, Syed RHK, Siddiqui SA, Raghavakaimal S, Terzic A, Jahangir A (2008) Aging-induced alterations in gene transcripts and functional activity of mitochondrial oxidative phosphorylation complexes in the heart. Mech Ageing Dev 129:304-312

Rexrode KM, Manson JE (2007) Are some types of hormone therapy safer than others? Lessons from the estrogen and thromboembolism risk study. Circulation 115:820-822

Rexrode KM, Ridker PM, Hegener HH, Buring JE, Manson JE, Zee RY (2007) Polymorphisms and haplotypes of the estrogen receptor-beta gene (ESR2) and cardiovascular disease in men and women. Clin Chem 53:17491756
Rezaul K, Wu L, Mayya V, Hwang SI, Han D (2005) A systematic characterization of mitochondrial proteome from human $\mathrm{T}$ leukemia cells. Mol Cell Proteomics 4:169-181

Salganicoff L, Fukami MH (1972) Energy metabolism of blood platelets. I. Isolation and properties of platelet mitochondria. Arch Biochem Biophys 153:726-735

Schwend T, Gustafsson JA (2006) False positives in MALDITOF detection of ERbeta in mitochondria. Biochem Biophys Res Commun 343:707-711

Trumpower BL, Edwards CA (1979) Identification of oxidation factor as a reconstitutively active form of the iron-sulfur protein of the cytochrome b-c1 segment of the respiratory chain. FEBS Lett 100:13-16

VanWijk MJ, VanBavel E, Sturk A, Nieuwland R (2003) Microparticles in cardiovascular diseases. Cardiovasc Res 59:277-287

Verhoeven AJ, Verhaar R, Gouwerok EG, de Korte D (2005) The mitochondrial membrane potential in human platelets: a sensitive parameter for platelet quality. Transfusion 45:82-89

Wadhawan V, Karim ZA, Mukhopadhyay S, Gupta R, Dikshit M, Dash D (2004) Platelet storage under in vitro condition is associated with calcium-dependent apoptosis-like lesions and novel reorganization in platelet cytoskeleton. Arch Biochem Biophys 422:183-190

Xu J, Shi C, Li Q, Wu J, Forster EL, Yew DT (2007) Mitochondrial dysfunction in platelets and hippocampi of senescence-accelerated mice. J Bioenerg Biomembr 39:195-202

Yang SH, Liu R, Perez EJ, Wen Y, Stevens SM Jr, Valencia T, Brun-Zinkernagel AM, Prokai L, Will Y, Dykens J, Koulen P, Simpkins JW (2004) Mitochondrial localization of estrogen receptor beta. Proc Natl Acad Sci USA 101:4130-4135

Zwaal RF, Schroit AJ (1997) Pathophysiologic implications of membrane phospholipid asymmetry in blood cells. Blood 89:1121-1132 